\title{
Ode to Glia: A Tribute to Bruce Ransom
}

\author{
Stephen G. Waxman ${ }^{1} \cdot$ Joel A. Black $^{1}$
}

Published online: 22 August 2017

(C) Springer Science+Business Media, LLC 2017

We met him at Stanford, back at the Farm

He impressed at first meeting... incredible charm

Neurologist - scientist par excellence

We liked him at once, more after some months

Dashing, smart, and incredibly handsome

The inimitable and brilliant Bruce Robert Ransom

From Valley to VA, and in between

Some of the best diagnoses we'd ever seen

He was great with a tuning fork and reflex hammer But Bruce also worked on the brain and its glamour

Neurons made most neuroscientists happy

But right from the start, Ransom was GFAPy

Astrocytes, astrocytes, everywhere serving From cortex to brainstem, and in the nerving (oops!)

Astros don't think, they don't spike, they are gluish Could they be Baptist? Methodist? Jewish?

In the mid 80s Ransom moved to Old Blue

But even at Yale, it was glue and more glue

From College to Yale Bowl, from Med School to Mory's

Stephen G. Waxman

stephen.waxman@yale.edu

1 Department of Neurology, Yale Medical School, New Haven, CT, USA
All we kept hearing was astrocyte stories

From pancake to star-like, and in between Astros and oligos were king and queen

Sontheimer, Stys, Fern and then Rose

O'Connor, I think, kept Bruce on his toes

Gray matter was elsewhere the focus of chatter

But Ransom was different, he liked the white matter

Then in '95 it was off to Seattle

Again came the star-cells, Bruce brought them like cattle.

He injured those astros, anoxic, ischemic, but as far as I know they were never anemic

And now we look back and we honor Bruce Ransom Glial cells, well, we all had a chance-um

But Bruce did it better and firster and smarter He understood glia... he took them aparter.

So we honor Bruce Ransom with a hearty Thank You, Our neurons are grateful...

Our glia are too 